\title{
Successive Determination of Copper and Iron by a Flow Injection- Catalytic Photometric Method Using a Serial Flow Cell
}

\author{
Shinsuke Ohno, Miho Tanaka, Norio TeShima, and Tadao SAKaI ${ }^{\dagger}$ \\ Department of Applied Chemistry, Aichi Institute of Technology, 1247 Yachigusa, Yakusa-cho, \\ Toyota, Aichi 470-0392, Japan
}

\begin{abstract}
A flow injection-catalytic spectrophotometric method using a serial flow cell was proposed for the successive determination of trace amounts of copper and iron. This method is based on the oxidation coupling of $p$-anisidine with $\mathrm{N}, \mathrm{N}$-dimethylaniline in the presence of hydrogen peroxide to form a dye, which has an absorption maximum at $740 \mathrm{~nm}$. In this indicator reaction, ligands such as 1,10-phenanthroline (phen) and diphosphate were achieved to improve the sensitivity and selectivity. Under the optimal experimental conditions, the determinable ranges were $0.05-5 \mathrm{ppb}$ for copper and $0.5-100 \mathrm{ppb}$ for iron, respectively. The RSDs $(n=10)$ were $0.78 \%$ for $0.5 \mathrm{ppb}$ copper(II) and $0.5 \%$ for 200 $\mathrm{ppb}$ iron(III). The sample throughput was $30 \mathrm{~h}^{-1}$. The present flow-injection method was applied to the determination of copper and iron in standard river water, tap water, and other natural water samples, and also to the analysis of labile and inert complexes in synthesized samples containing humic acid with copper(II) or iron(III).
\end{abstract}

(Received August 21, 2003; Accepted October 17, 2003)

\section{Introduction}

Trace amounts of copper and iron exist widely in river, tap, pond, well, and underground water. These metals are essential trace elements for biological systems. Numerous dissolving chemical forms, such as aqua ions, complexes and colloids, are observed in natural water. In general, the toxicity of dissolved copper(II) is considered to be much less than that of mercury, but greater than that of cadmium, silver, lead, and zinc. However, it has been reported that chelating agents, such as nitrilotriacetic acid and ethylenediaminetetraacetic acid, decreased the toxicity of copper. ${ }^{2}$ The concentration levels of these metals existing in natural water are trace and/or ultratrace. Therefore, a highly sensitive analytical method for the determination of copper and iron is required to investigate water pollution.

Kinetic-catalytic methods based on catalyzed reactions have been developed for the determination of manganese, chromium, cobalt, and vanadium ions at trace and ultratrace levels. ${ }^{3-6}$ Kawashima et al. have determined ppb levels of iron in tap and hot-spring water samples. ${ }^{7}$ Recently, the present authors also reported a catalytic method for the determination of copper using a flow-injection system. ${ }^{8}$ On the other hand, adsorptive cathodic stripping voltammetry (ACSV) was proposed to measure copper in seawater at trace levels. ${ }^{9}$ However, one of the major problems in ACSV is the adsorption of organic compounds on the electrode. ${ }^{10}$

The kinetic-catalytic methods require a controlled reaction temperature, time, and constant mixing of the reagents. Thus, flow injection analysis (FIA), which has advantages of rapidity and easy assembly, is efficient to control serious experimental conditions. However, it is difficult to successively determine

$\doteqdot$ To whom correspondence should be addressed.

E-mail: tadsakai@aitech.ac.jp several analytes by an FIA system equipped with a conventional flow cell. Recently, Sakai and his co-workers designed twochannel double and serial flow cells ${ }^{11}$ and a twin flow cell ${ }^{12}$ for the simultaneous determination of copper and iron with 2-(5bromo-2-pyridylazo)-5-[N-n-propyl- $N$-(3-sulfopropyl)amino]aniline, sodium salt (5-Br-PSAA) or 2-(5-nitro-2pyridylazo)-5-[ $N-n$-propyl- $N$-(3-sulfopropyl)amino]phenol, disodium salt, dihydrate (Nitro-PAPS). However, these methods using chromogenic reagents were not sufficient for the determination of sub-ppb levels of copper and iron. Also, it is difficult to analyze the complexation reactions of ppb levels of copper and iron with ligands, such as humic and fulvic acids. During the recent decade, some researchers have reported on catalytic methods for binary metal mixtures, such as silver(I)mercury(II), ${ }^{13}$ chromium(VI)-tungsten(VI), ${ }^{14}$ and iron(II)antimonony(III). ${ }^{15}$ However, there are few reports on kineticcatalytic methods for the determination of two catalysts using a single indicator reaction.

In the presence of hydrogen peroxide, $p$-anisidine reacted with $N, N$-dimethylaniline (DMA) to form a dye $\left(\lambda_{\max }=740 \mathrm{~nm}\right)$. Although the oxidative coupling reaction was slow, the reaction rate was accelerated in the presence of copper(II) ${ }^{16}$ or iron(III). ${ }^{17}$ Since the absorbance of the dye formed at a fixed time was proportional to these metal concentrations, it was possible to determine copper(II) and iron(III). In a previous paper,,$^{18}$ this kinetic-catalytic analysis was performed to determine copper(II) and iron(III) selectively by a batchwise method.

This paper describes a catalytic method using an FIA system equipped with a serial flow cell for the successive determination of copper(II) and iron(III) at sub-ppb levels in natural water samples, because the sensitivity and selectivity can be improved. The proposed method can be applied to the determination of trace amounts of copper(II) and iron(III), and also to the determination of labile and inert complexes in synthesized samples involving humic acid and copper(II) or iron(III) 


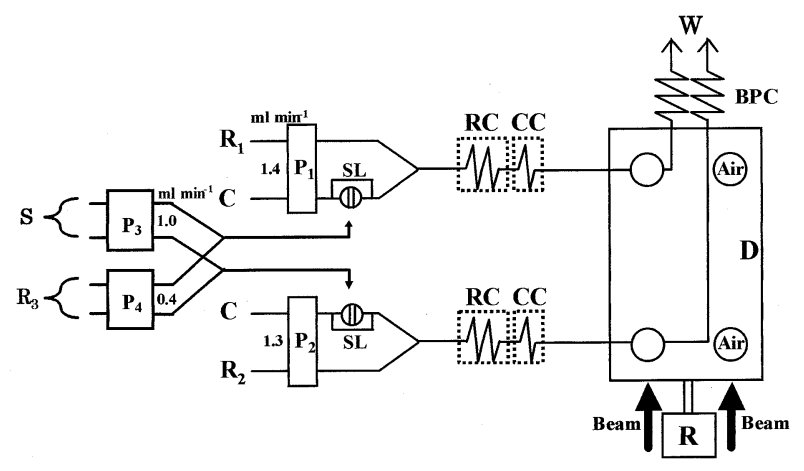

Fig. 1 Schematic diagram of a flow-injection system equipped with a serial flow cell: $\mathrm{C}$, carrier solution $(0.5 \mathrm{M}$ hydrogen peroxide at $\mathrm{pH}$ 2); $\mathrm{R}_{1}(0.08 \mathrm{M} p$-anisidine, $0.06 \mathrm{M}$ DMA, $0.2 \mathrm{M}$ acetate buffer ( $\mathrm{pH}$ 3.1), $2 \times 10^{-3} \mathrm{M}$ diphosphate); $\mathrm{R}_{2}$ (0.06 M $p$-anisidine, $0.06 \mathrm{M}$ DMA, $0.2 \mathrm{M}$ acetate buffer ( $\mathrm{pH} 3.1$ ), $2 \times 10^{-3} \mathrm{M}$ diphosphate, $2 \times 10^{-3} \mathrm{M}$ phen); $\mathrm{P}_{1}$ and $\mathrm{P}_{2}$, pumps; SL, sample loop $(2 \mathrm{~m} \times \phi 0.5 \mathrm{~mm})$; RC, reaction coil $\left(8 \mathrm{~m} \times \phi 0.5 \mathrm{~mm}, 90^{\circ} \mathrm{C}\right)$; $\mathrm{CC}$, cooling coil $(1 \mathrm{~m} \times \phi 0.5$ $\mathrm{mm})$; BPC, back pressure coil $(35 \mathrm{~cm} \times \phi 0.25 \mathrm{~mm})$; D, double beam spectrophotometer equipped with a serial flow cell $(740 \mathrm{~nm})$; R, recorder; $\mathrm{W}$, waste; $\mathrm{S}$, sample; $\mathrm{R}_{3}, 3 \mathrm{M}$ hydrogen peroxide at $\mathrm{pH} 2 ; \mathrm{P}_{3}$ and $\mathrm{P}_{4}$, peristaltic pumps.

\section{Experimental}

\section{Reagents}

All of the reagents were of analytical-reagent grade and were used without further purification. All solutions were prepared with deionized water purified with an Advantec Aquarius GSH210 system.

Commercially available $1000 \mathrm{ppm}$ copper(II) and iron(III) standard solutions for atomic absorption spectrophotometry (Wako, Osaka) were used. Working solutions of copper and iron were prepared by appropriate dilution of the standard solutions with $0.01 \mathrm{M}\left(=\mathrm{mol} \mathrm{dm}{ }^{-3}\right)$ hydrochloric acid.

A $0.25 \mathrm{M} p$-anisidine solution was prepared by dissolving $15.4 \mathrm{~g}$ of $p$-anisidine (Wako) in $150 \mathrm{ml}$ of conc. hydrochloric acid and made up to $500 \mathrm{ml}$ with water.

A 0.6 M DMA solution was prepared by dissolving $36.4 \mathrm{~g}$ of DMA (Wako) in $90 \mathrm{ml}$ of $4 \mathrm{M}$ hydrochloric acid and made up to $500 \mathrm{ml}$ with water.

A $2 \mathrm{M}$ acetic acid solution was prepared by diluting $60 \mathrm{ml}$ of acetic acid (Sigma Aldrich Japan, Tokyo) to $500 \mathrm{ml}$ with water. A $2 \mathrm{M}$ sodium acetate solution was prepared by dissolving 27.2 $\mathrm{g}$ of sodium acetate trihydrate (Nacalai Tesque, Kyoto) with water and made up to $100 \mathrm{ml}$ with water. These solutions were mixed to prepare a buffer solution $(\mathrm{pH} 3.1)$.

A $0.1 \mathrm{M}$ diphosphate solution was prepared by dissolving $2.23 \mathrm{~g}$ of sodium diphosphate decahydrate (Wako) with $50 \mathrm{ml}$ of water.

A $0.25 \mathrm{M}$ 1,10-phenanthroline (phen) solution was prepared by dissolving $4.96 \mathrm{~g}$ of 1,10-phenanthroline monohydrate (Dojindo Laboratories, Kumamoto) with $8 \mathrm{ml}$ of $4 \mathrm{M}$ hydrochloric acid.

Hydrogen peroxide solutions $(0.5$ and $3 \mathrm{M})$ were prepared by diluting appropriate amounts of $30 \%$ hydrogen peroxide with $0.01 \mathrm{M} \mathrm{HCl}$.

\section{Apparatus}

Figure 1 shows a schematic diagram of a flow-injection system using a serial flow cell for the successive determination

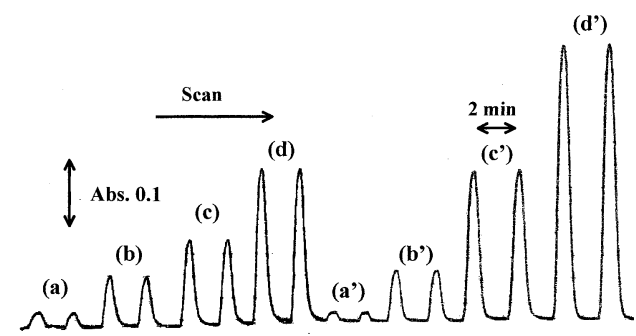

Fig. 2 Flow signals for copper(II) and iron(III) using a serial flow cell: (a) and (a'), blank peaks for copper(II) and iron(III); (b) and (b'), $0.5 \mathrm{ppb}$ copper(II) and $20 \mathrm{ppb}$ iron(III); (c) and (c'), $1 \mathrm{ppb}$ copper(II) and $50 \mathrm{ppb}$ iron(III); (d) and (d'), 2 ppb copper(II) and 100 ppb iron(III). Other conditions are the same as in Fig. 1.

of copper(II) and iron(III). The system consisted of two doubleplunger pumps (DMX-2000, Sanuki Kogyo, Tokyo and Type DUAL PUMP201, F.I.A Instrument, Tokyo), two six-way injection valves (SVM-6M2, Sanuki Kogyo), two thermostated baths (R-3000C, Sanuki Kogyo and Type 521, F.I.A Instrument), a spectrophotometer (S-3250, Soma Optics, Tokyo) equipped with a serial flow cell (cell volume, $4 \mu \mathrm{l}$; path length, $5 \mathrm{~mm}),{ }^{11}$ two peristaltic pumps (U4-8R, Alitea, Sweden) and a recorder (EB22005, Chino, Tokyo). All connecting lines and reaction coils were made from $0.5 \mathrm{~mm}$ i.d. Teflon tubing. A Horiba Model F-22 pH/mV meter was used for $\mathrm{pH}$ adjustment.

\section{Procedure}

A carrier solution $(\mathrm{C}, 0.5 \mathrm{M}$ hydrogen peroxide at $\mathrm{pH} 2)$ and a $\mathrm{R}_{1}$ solution ( $0.08 \mathrm{M} p$-anisidine, $0.06 \mathrm{M}$ DMA, $0.2 \mathrm{M}$ acetate buffer at $\mathrm{pH} 3.1$ and $2 \times 10^{-3} \mathrm{M}$ diphosphate) were delivered at $0.65 \mathrm{ml} \mathrm{min}^{-1}$ by pump $1\left(\mathrm{P}_{1}\right)$. The carrier solution (described above) and an $\mathrm{R}_{2}$ solution (0.06 $\mathrm{M} p$-anisidine, $0.06 \mathrm{M}$ DMA, $0.2 \mathrm{M}$ acetate buffer at $\mathrm{pH} 3.1,2 \times 10^{-3} \mathrm{M}$ diphosphate and $2 \times$

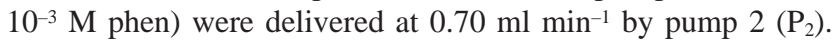
The sample $(\mathrm{S})$ and $3 \mathrm{M}$ hydrogen peroxide $\left(\mathrm{pH} 2, \mathrm{R}_{3}\right)$ solutions were delivered by two peristaltic pumps $\left(\mathrm{P}_{3}, \mathrm{P}_{4}\right)$. These mixed solutions were loaded in two sample loops $(2 \mathrm{~m})$ attached to valves $\mathrm{V}_{1}$ and $\mathrm{V}_{2}$, and these solutions were injected into the carrier solutions. The absorbance of the dye formed in the reaction coil ( $\mathrm{RC})$ and the cooling coil $(\mathrm{CC})$ was monitored at $740 \mathrm{~nm}$ using a double-beam spectrophotometer equipped with a serial flow cell and recorded on a recorder. Figure 2 shows flow signals for copper(II) and iron(III) obtained using a serial flow cell.

\section{Results and Discussion}

\section{Effects of activators on the catalytic reactions}

The use of a suitable activator in the kinetic-catalytic methods can enhance the catalytic effect of specific metal ions, and then the selectivity and sensitivity can be also improved.

The activating effects of several polypyridines, such as phen, 2,9-dimethyl-1,10-phenanthroline (neocuproine), bathophenanthrolinedisulfonate (BPS), and bathocuproine-disulfonate (BCS), were investigated. Figure 3 (a) shows the effects of the phen concentration on the copper- and iron-catalyzed reactions in the range from 0 to $1 \times 10^{-2} \mathrm{M}$. Phen enhanced the catalytic action of iron(III) and acted as an inhibitor for copper(II). The conditional redox potential of the $\mathrm{Fe}(\mathrm{III}) / \mathrm{Fe}(\mathrm{II})$ system increased in the presence of phen; the overall formation 

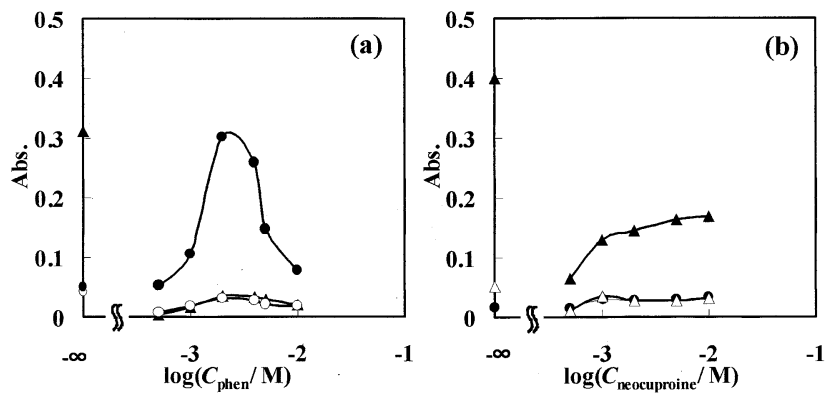

Fig. 3 Effects of the activator concentrations of (a) phen and (b) neocuproine on the copper(II) and iron(III) determination: (•), 50 ppb iron(III); ( o), blank for iron(III) determination system; ( $\mathbf{\Delta}), 5$ ppb copper(II); $(\Delta)$, blank for copper(II) determination system Other conditions are the same as in Fig. 1.
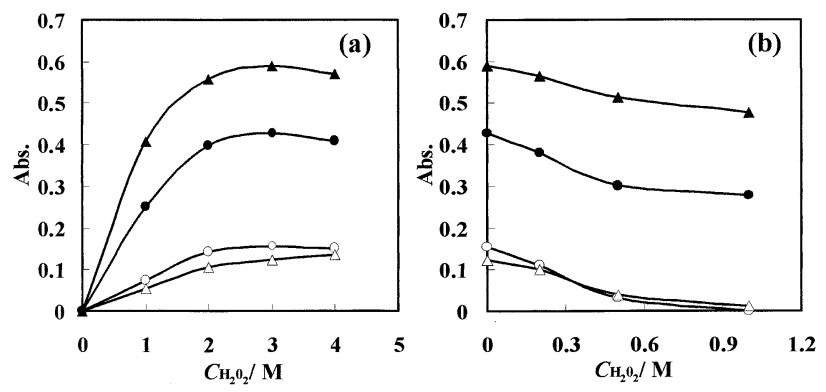

Fig. 4 Dependences of copper(II) and iron(III) signals on the hydrogen peroxide concentration of (a) sample and (b) carrier: ( $\mathbf{\Delta})$, $50 \mathrm{ppb}$ iron(III); $(\triangle)$, blank for iron(III) determination system; (•), 5 ppb copper(II); ( $)$, blank for copper(II) determination system. Other conditions are the same as in Fig. 1.

constant of the $\mathrm{Fe}(\mathrm{II})$-phen complex $\left(\log \beta_{3}=21.3\right)$ is larger than that of the Fe(III)-phen complex $\left(\log \beta_{3}=14.1\right) .{ }^{19}$ Therefore, it was obvious that the coexisting phen enhanced the oxidation power of $\mathrm{Fe}(\mathrm{III})$. The absorbance of the produced dye in the presence of iron(III) increased up to $2 \times 10^{-3} \mathrm{M}$ phen, and then the absorbance gradually decreased over that concentration. It seems that the activator was attributable to form ternary complexs of the activator-metal-substrate ${ }^{20}$ pheniron- $p$-anisidine and/or phen-iron-DMA. Similarly, the effect of BPS was also studied on the iron-catalyzed dye-formation reaction. However, the absorbance in the presence of BPS was lower than that of phen, because BPS might cause a steric hindrance on the ternary complex formation. Thus, a $2 \times 10^{-3}$ $M$ phen concentration was selected in the iron(III) determination system.

The effects of neocuproine concentrations were investigated on each metal determination system. Neocuproine did not act as an effective activator for copper(II) and iron(III) in the range from 0 to $1 \times 10^{-2} \mathrm{M}$. This result is shown in Fig. 3 (b). Although neocuproine acted as an activator for the coppercatalyzed reaction, ${ }^{18}$ the same result could not be observed in this study. Neocuproine acted as an activator for a coppercatalyzed reaction when the DMA concentration was $0.02-0.03$ $\mathrm{M}$ and the $p$-anisidine concentration was $0.01 \mathrm{M}$. On the other hand, neocuproine acted as an inhibitor for copper(II) if the concentration of $p$-anisidine was more than $0.02 \mathrm{M}$. Thus, the activator for copper(II) determination was not used in the present FIA study.
Table 1 Recoveries of copper(II) and iron(III) with and without diphosphate

\begin{tabular}{|c|c|c|c|c|c|}
\hline \multirow{2}{*}{\multicolumn{2}{|c|}{ Added, ppb }} & \multicolumn{4}{|c|}{ Found, ppb (Recovery, \%) } \\
\hline & & \multicolumn{2}{|c|}{$\mathrm{Cu}$} & \multicolumn{2}{|c|}{$\mathrm{Fe}$} \\
\hline $\mathrm{Cu}$ & $\mathrm{Fe}$ & With & Without & With & Without \\
\hline 5 & 50 & $5.16(103)$ & $6.01(120)$ & $51.3(103)$ & $63.7(127)$ \\
\hline 1 & 20 & 0.99 ( 99 ) & $1.06(106)$ & $20.1(101)$ & $28.8(144)$ \\
\hline 1 & 50 & $1.04(104)$ & $1.11(111)$ & $49.5(99)$ & $65.2(130)$ \\
\hline
\end{tabular}

\section{Effect of diphosphate on the determination of copper(II) and} iron(III)

In a previous study, ${ }^{18}$ diphosphate was effective as a masking agent to determine copper(II) and iron(III) successively. The effects of diphosphate for copper(II) and iron(III) were investigated using the FIA system. The recoveries are given in Table 1. The recoveries in the absence of diphosphate were over $100 \%$. This is because copper(II) and iron(III) catalyze in the same indicator reaction. In the presence of diphosphate, the recoveries of copper(II) and iron(III) were around 100\%, because all catalytic actions were slightly inhibited.

The effect of the diphosphate concentration on the copperand iron-catalyzed dye formation was investigated. The interferences on each element were restricted with increasing the diphosphate concentration. It seems that the complex formation of these metals with diphosphate occurred. In addition, the peak heights of the reagent blank were depressed in the presence of diphosphate. Thus, $2 \times 10^{-3} \mathrm{M}$ diphosphate was selected for each determination of copper(II) and iron(III).

\section{Optimization of the hydrogen peroxide concentration}

The hydrogen peroxide concentration in samples was varied from 0 to $4 \mathrm{M}$. The absorbance of the dye increased with increasing the hydrogen peroxide concentration. Therefore, 3 $\mathrm{M}$ hydrogen peroxide was selected for the determinations of copper(II) and iron(III). However, the peak heights of the reagent blank became high with an increase in the concentration of hydrogen peroxide. Consequently, hydrogen peroxide was added to each carrier solution $(\mathrm{pH} 2)$ to reduce blank peak heights. The concentration was varied from 0 to $1 \mathrm{M}$. The results are shown in Figs. 4 (a) and (b). All blank peak heights were reduced with increasing the concentration in the carriers. Thus, the hydrogen peroxide concentrations in the carriers and sample solution were selected to be 0.5 and $3 \mathrm{M}$, respectively.

\section{Optimization of the $\mathrm{pH}$}

The effects of the $\mathrm{pH}$ were investigated over the range of $2.1-$ 3.5 for copper(II) and 2.3-3.4 for iron(III). The $\mathrm{pH}$ was measured after merging in the tube. In both catalysts, the highest peak height was obtained at around $\mathrm{pH} 2.8$. Therefore, the reaction $\mathrm{pHs}$ were fixed at $\mathrm{pH} 2.8$.

\section{Optimization of the reaction temperature}

The effects of the reaction temperature on the dye formation in both the absence and presence of copper(II) and iron(III) were studied in the range from 24 to $95^{\circ} \mathrm{C}$. The peak heights increased with an increase in the temperature in the presence of catalysts. On the other hand, the peak heights in the absence of catalysts were low. Thus, the reaction temperature was selected to be $90^{\circ} \mathrm{C}$. 
Table 2 Experimental conditions by the proposed FIA method

\begin{tabular}{|c|c|}
\hline $\mathrm{Cu}$ & $\mathrm{Fe}$ \\
\hline $0.08 \mathrm{M} p$-Anisidine & $0.06 \mathrm{M} p$-Anisidine \\
\hline 0.06 M DMA & 0.06 M DMA \\
\hline $0.2 \mathrm{M}$ Acetate buffer ( $\mathrm{pH} 3.1$ ) & $0.2 \mathrm{M}$ Acetate buffer $(\mathrm{pH} 3.1)$ \\
\hline $2 \times 10^{-3} \mathrm{M}$ Diphosphate & $\begin{array}{l}2 \times 10^{-3} \mathrm{M} \text { Diphosphate } \\
2 \times 10^{-3} \mathrm{M} \text { Phen }\end{array}$ \\
\hline $0.5 \mathrm{M} \mathrm{H}_{2} \mathrm{O}_{2}$ at $\mathrm{pH} 2$ (carrier) & $0.5 \mathrm{M} \mathrm{H}_{2} \mathrm{O}_{2}$ at $\mathrm{pH} 2$ (carrier) \\
\hline $3 \mathrm{M} \mathrm{H}_{2} \mathrm{O}_{2}$ at pH 2 (inject) & $3 \mathrm{M} \mathrm{H}_{2} \mathrm{O}_{2}$ at $\mathrm{pH}$ 2(inject) \\
\hline $\mathrm{RC} 8 \mathrm{~m}, 90^{\circ} \mathrm{C}, \phi 0.5 \mathrm{~mm}$ & $\mathrm{RC} 8 \mathrm{~m}, 90^{\circ} \mathrm{C}, \phi 0.5 \mathrm{~mm}$ \\
\hline $\mathrm{CC} 1 \mathrm{~m}, \phi 0.5 \mathrm{~mm}$ & $\mathrm{CC} 1 \mathrm{~m}, \phi 0.5 \mathrm{~mm}$ \\
\hline SL $2 \mathrm{~m}, \phi 0.5 \mathrm{~mm}$ & SL $2 \mathrm{~m}, \phi 0.5 \mathrm{~mm}$ \\
\hline BPC $35 \mathrm{~cm}, \phi 0.25 \mathrm{~mm}$ & BPC $35 \mathrm{~cm}, \phi 0.25 \mathrm{~mm}$ \\
\hline Flow rate, $1.4 \mathrm{ml} \mathrm{min}^{-1}$ & Flow rate, $1.3 \mathrm{ml} \mathrm{min}^{-1}$ \\
\hline$\lambda_{\max }, 740 \mathrm{~nm}$ & $\lambda_{\max }, 740 \mathrm{~nm}$ \\
\hline
\end{tabular}

Table 3 Recovery tests of copper(II) and iron(III) in mixed solutions

\begin{tabular}{|c|c|c|c|c|c|}
\hline \multicolumn{2}{|c|}{ Added, ppb } & \multicolumn{2}{|c|}{ Found, ppb } & \multicolumn{2}{|c|}{ Recovery, \% } \\
\hline $\mathrm{Cu}$ & $\mathrm{Fe}$ & $\mathrm{Cu}$ & $\mathrm{Fe}$ & $\mathrm{Cu}$ & $\mathrm{Fe}$ \\
\hline 0.5 & 20 & 0.51 & 19.6 & 101 & 98 \\
\hline 0.5 & 50 & 0.52 & 52.0 & 104 & 104 \\
\hline 0.5 & 100 & 0.50 & 95.7 & 100 & 96 \\
\hline 1 & 10 & 0.99 & 9.76 & 99 & 98 \\
\hline 1 & 100 & 0.96 & 99 & 96 & 99 \\
\hline 1 & 200 & 1.05 & - & 105 & - \\
\hline 2 & 100 & 2.10 & 99 & 105 & 99 \\
\hline 2 & 200 & 2.09 & - & 105 & - \\
\hline
\end{tabular}

\section{Optimization of other variables}

The effects of other reagent concentrations were examined. The $p$-anisidine concentration was varied from 0 to $0.1 \mathrm{M}$. The absorbance increased with increasing its concentration. The 0.1 $\mathrm{M}$ and $0.08 \mathrm{M} p$-anisidine concentrations were selected for copper(II) and iron(III), respectively. The DMA concentration was varied from 0 to $0.08 \mathrm{M}$. In this study, $0.06 \mathrm{M}$ DMA was used. The reaction coil length was varied from 2 to $10 \mathrm{~m}$ on the copper-(or iron-)catalyzed dye-forming reaction. When the length became longer than $6 \mathrm{~m}$ for copper(II) and $8 \mathrm{~m}$ for iron(III), the absorbance of the dye increased. Thus, a reaction coil length of $8 \mathrm{~m}$ was selected for the determination of copper(II) and iron(III). The slower flow rate resulted in an increase of the absorbance because the reaction time was longer. Flow rates of 1.3 and $1.4 \mathrm{ml} \mathrm{min}{ }^{-1}$ were used for the copper(II) and iron(III) determination, respectively. The sample loops $(0.5$ $\mathrm{mm}$ i.d.) for the copper- and iron-assay system were varied from 0.5 to $3 \mathrm{~m}$. Taking into account the sensitivity and repeatability, sample loops of $2 \mathrm{~m}$ were selected.

\section{Calibration curves for copper(II) and iron(III)}

The calibration curves for copper(II) and iron(III) were prepared under the optimum conditions (Table 2). The dynamic ranges were $0.05-5 \mathrm{ppb}$ for copper(II) and $0.5-100 \mathrm{ppb}$ for iron(III), respectively. The sampling rate was $30 \mathrm{sample}^{-1}$ for each analysis. The repeatabilities by the FIA system were $0.96 \%$ and $0.46 \%$ for 0.5 and $2 \mathrm{ppb}$ copper(II), $0.78 \%$ and $0.45 \%$ for 20 and $50 \mathrm{ppb}$ iron(III), respectively. The detection limits $(S / N=3)$ were $10 \mathrm{ppt}$ for copper(II) and $100 \mathrm{ppt}$ for iron(III).
Table 4 Interference of foreign ions in the successive determination of $2 \mathrm{ppb}$ copper(II) and $50 \mathrm{ppb}$ iron(III)

\begin{tabular}{rll}
\hline Added $^{2} / \mathrm{ppb}$ & \multicolumn{1}{c}{$\mathrm{Cu}$} & \multicolumn{1}{c}{$\mathrm{Fe}$} \\
\hline \multirow{2}{*}{50000} & $\mathrm{~K}(\mathrm{I}), \mathrm{Mg}(\mathrm{II}), \mathrm{SO}_{4}{ }^{2-}, \mathrm{Cl}^{-}$, & $\mathrm{K}(\mathrm{I}), \mathrm{Na}(\mathrm{I}), \mathrm{SO}_{4}{ }^{2-}, \mathrm{Cl}^{-}, \mathrm{NO}_{3}{ }^{-}$ \\
& $\mathrm{NO}_{3}{ }^{-}$ & \\
20000 & $\mathrm{Na} \mathrm{I}), \mathrm{Ca}(\mathrm{II})$ & $\mathrm{Cd}(\mathrm{I}), \mathrm{BO}_{3}{ }^{3-}, \mathrm{Mg}(\mathrm{II}), \mathrm{Ca}(\mathrm{II})$ \\
10000 & $\mathrm{BO}_{3}{ }^{3-}, \mathrm{Cd}(\mathrm{II})$ & $\mathrm{Zn}(\mathrm{II})$ \\
5000 & $\mathrm{Mn}(\mathrm{II}), \mathrm{Co}(\mathrm{II})$ \\
1000 & $\mathrm{Co}(\mathrm{II})$, & $\mathrm{Pb}(\mathrm{II})$ \\
500 & $\mathrm{Mn}(\mathrm{II}), \mathrm{Zn}(\mathrm{II}), \mathrm{Al}(\mathrm{III})$ \\
200 & $\mathrm{~Pb}(\mathrm{II}), \mathrm{Cr}(\mathrm{VI}), \mathrm{Ni}(\mathrm{II})$ & $\mathrm{Cr}(\mathrm{VI}), \mathrm{Al}(\mathrm{III}), \mathrm{Ni}(\mathrm{II})$ \\
\hline
\end{tabular}

a. Tolerable concentraion with the tolerance range $95-105 \%$, which means within $5 \%$ error in analysis.

Table 5 Simultaneous determination of copper and iron in standard river water ${ }^{\mathrm{a}}$

\begin{tabular}{rccccc}
\hline \multirow{2}{*}{ Sample } & \multicolumn{2}{c}{ Found $^{\mathrm{b}}, \mathrm{ppb}$} & & \multicolumn{2}{c}{ Certified value, $\mathrm{ppb}$} \\
\cline { 2 - 3 } \cline { 5 - 6 } & $\mathrm{Cu}$ & $\mathrm{Fe}$ & & $\mathrm{Cu}$ & $\mathrm{Fe}$ \\
\hline JAC 0031 & $0.91 \pm 0.03^{\mathrm{c}}$ & $7.5 \pm 0.2^{\mathrm{c}}$ & & $0.88 \pm 0.3$ & $6.9 \pm 0.5$ \\
JAC 0032 & $10.4 \pm 0.1^{\mathrm{c}}$ & $56 \pm 1^{\mathrm{c}}$ & & $10.5 \pm 0.2$ & $57 \pm 2$ \\
\hline
\end{tabular}

a. Purchased from the Japan Society for Analytical Chemistry.

b. Average value for 10 determinations.

c. The river water was diluted 5 times.

Successive determinations of copper(II) and iron(III) in artificial mixtures were studied. The results are given in Table 3. An error of $5 \%$ was considered to be tolerable. The concentration ranges were $0.5-2 \mathrm{ppb}$ for copper and 10-200 $\mathrm{ppb}$ for iron. The $100 \mathrm{ppb}$ iron(III) showed no interference in the determination of $0.5 \mathrm{ppb}$ copper(II). On the other hand, 10 $\mathrm{ppb}$ iron(III) did not interfere in the determination of $1 \mathrm{ppb}$ copper(II).

\section{Interferences of foreign ions in the determination of copper(II)} and iron(III)

The interferences of foreign ions in the determination of a mixture of 2 ppb copper(II) and 50 ppb iron(III) were examined. The results are summarized in Table 4, where the tolerable concentrations of foreign ions are shown in each case. An error of $5 \%$ was considered to be tolerable. Most of the metal ions and inorganic anions did not interfere in the determinations of copper(II) and iron(III) for concentrations of up to at least 200 ppb.

\section{Application to standard river water samples and real samples}

The proposed method using a serial flow cell was applied to the successive determination of copper(II) and iron(III) in standard river water samples (JAC 0031 and 0032) issued from the Japan Society for Analytical Chemistry. These samples were diluted 5 times with water. Since the $\mathrm{pH}$ of the diluted river water was 1.9 , it was no problem to determine copper and iron. The results are given in Table 5. Copper and iron obtained by the proposed method were in good agreement with the certified values.

To examine the applicability of the proposed method, copper(II) (0-0.5 ppb) and iron(III) (0-5 ppb) standard solutions were added to tap, rain, and well water samples. These real samples were acidified by adding conc. hydrochloric 
Table 6 Determination of copper and iron in tap and natural water samples

\begin{tabular}{lcclll}
\hline \multirow{2}{*}{ Sample } & \multicolumn{2}{c}{ Dilution } & & \multicolumn{2}{c}{ In sample, ppb } \\
\cline { 2 - 3 } \cline { 5 - 6 } & $\mathrm{Cu}$ & $\mathrm{Fe}$ & & $\mathrm{Cu}$ & $\mathrm{Fe}$ \\
\hline Tap & 5 & 5 & & $1.36 \pm 0.06$ & $63.4 \pm 0.6$ \\
Rain & 1.25 & 1.25 & & $0.35 \pm 0.00$ & $1.78 \pm 0.02$ \\
Well 1 & 20 & 20 & & $5.05 \pm 0.19$ & $82.4 \pm 0.8$ \\
Well 2 & 20 & 50 & & $73.8 \pm 0.5$ & $43.0 \pm 3.4$ \\
\hline
\end{tabular}

Table 7 Measurement of labile and inert complexes at pH 5.6 and 1 in artificial samples containing humic acid with copper(II) or iron(III)

\begin{tabular}{|c|c|c|c|c|c|}
\hline \multicolumn{2}{|c|}{ Added, ppb } & \multicolumn{2}{|c|}{$\mathrm{Cu}$ found, $\mathrm{ppb}$} & \multicolumn{2}{|c|}{ Fe found, ppb } \\
\hline $\mathrm{Cu}: \mathrm{Hu}^{\mathrm{a}}$ & $\mathrm{Fe}: \mathrm{Hu}^{\mathrm{a}}$ & pH 5.6 & pH 1 & pH 5.6 & pH 1 \\
\hline $4: 100$ & 100:500 & $2.5 \pm 0.0$ & $3.5 \pm 0.1$ & $47.1 \pm 0.8$ & $89.5 \pm 1.0$ \\
\hline $4: 200$ & 100:1000 & $1.9 \pm 0.0$ & $3.2 \pm 0.1$ & $24.8 \pm 1.1$ & $85.2 \pm 0.4$ \\
\hline
\end{tabular}

a. Humic acid.

acid to $\mathrm{pH} c a .2$ after filtering through a Millipore membrane filter $(0.45 \mu \mathrm{m}$ pore size). The results are given in Table 6 . In these experiments, good recoveries of copper(II) and iron(III) were obtained, ranging from 94 to 104\% (mean 99\%).

Measurement of labile and inert complexes at pH 5.6 and 1

Artificial samples containing humic acid and copper(II) (or iron(III)) were prepared. The copper(II) concentration was 4 $\mathrm{ppb}$ and that of iron(III) was $100 \mathrm{ppb}$. Then, the labile and inert complexes at $\mathrm{pH} 5.6$ and 1 were analyzed using the proposed method. The results are given in Table 7. The recoveries of copper(II) and iron(III) at pH 5.6 were smaller than their added amounts. The results indicate that copper(II) and iron(III) may form inert complexes with humic acid. However, the recovered amounts of copper(II) and iron(III) at $\mathrm{pH} 1$ were larger than those at $\mathrm{pH}$ 5.6, which suggests the dissociation of each humic acid complex at a lower $\mathrm{pH}$.

\section{Conclusion}

Trace amounts of copper(II) and iron(III) could be successively determined by the proposed FIA system equipped with a serial flow cell, based on their catalytic effects. The proposed FIA system has wider determinable ranges of 0.05 - 5 ppb copper(II) and $0.5-100 \mathrm{ppb}$ iron(III), respectively. This method was successfully applied to the determination of copper(II) and
iron(III) in standard river water samples as well as tap, rain, and well water samples without any preconcentration or separation. Also, it was useful to assay labile copper(II) and iron(III) complexes in natural water.

\section{Acknowledgements}

This work was partly supported by a Grant of the Science Research Promotion Fund from the Promotion and Mutual Aid Corporation for Private Schools of Japan.

\section{References}

1. T. M. Florence and G. E. Batley, Talanta, 1977, 24, 151.

2. J. B. Sprague, Nature, 1968, 220, 1345.

3. Y. Miyata, T. Hirano, S. Nakano, and T. Kawashima, Anal. Sci., 1991, 7, 97.

4. S. Nakano, S. Hinokuma, and T. Kawashima, Chem. Lett., $1983,357$.

5. Z. Yu, N. Teshima, S. Nakano, and T. Kawashima, Talanta, 1996, 43, 1519.

6. S. Nakano, M. Tago, and T. Kawashima, Anal. Sci., 1989, 5,69 .

7. T. Tomiyasu, N. Yonehara, N. Teshima, and T. Kawashima, Anal. Chim. Acta, 1999, 394, 55.

8. J. Wei, N. Teshima, S. Ohno, and T. Sakai, Anal. Sci. 2003, 19, 731 .

9. G. Scarano, E. Morelli, A. Seritti, and A. Zirino, Anal. Chim. Acta, 1990, 62, 943.

10. K. Yokoi, T. Tomisaki, T. Koide, and C. M. G. van den Berg, Fresenius' J. Anal. Chem., 1995, 352, 547.

11. T. Sakai, Y. Maeda, and N. Ura, Talanta, 1999, 49, 989.

12. S. Gotoh, N. Teshima, T. Sakai, K. Ida, and N. Ura, Anal. Chim. Acta, in press.

13. J. Wang and R. He, Anal. Chim. Acta, 1994, 294, 195.

14. Z. Zhu, C. Han, Z. Gu, and R. Chen, Analyst, 1994, 119, 2251.

15. W. Jianhua and H. Ronghuan, Mikrochim. Acta, 1994, 117, 23.

16. S. Nakano, K. Kuramoto, and T. Kawashima, Chem. Lett., 1980, 849 .

17. T. Kawashima, Y. Kozuma, and S. Nakano, Anal. Chim. Acta, 1979, 106, 355.

18. S. Ohno, N. Teshima, H. Zhang, and T. Sakai, Talanta, 2003, 60, 1177

19. W. A. E. McBryde, "A Critical Review of Equilibrium Data for Proton- and Metal Complexes of 1,10-phenanthroline, 2,2'-Bipyridyl and Related Compounds", 1978, Pergamon Press, Oxford.

20. P. R. Bontchev, Talanta, 1972, 19, 675. 